\title{
Uusi oppimisnäkemys ja kehittyvä työntutkimus ${ }^{1)}$
}

\section{Yhteiskunnallisen ja psykologisen välinen kaksijakoisuus}

Kuten niin monia radikaalin opiskelijaliikkeen sukupolveen kuuluvia, minua kannusti tutkimustyötäni aloittaessani pakottava tarve voittaa inhimillisen elämän yhteiskunnallisen ja psykologisen puolen välillä vallitseva kaksijakoisuus. Tämä kaksijakoisuus esittää yhteiskunnan rakenteena, jossa ihmiset esiintyvät pääasiassa välttämättömänä raaka-aineena tai nukkeina, eivät rakentajina. Ja se esittää yksilön riippumattomana kotelona, jonka sisäisiä tiloja, henkisiä ominaisuuksia, reaktioita ja tekoja on tutkittava sellaisinaan ottaen yhteiskunta huomioon vain joukkona taustamuuttujia, jos ollenkaan.

Otin aluksi lähtökohdakseni yhteiskunnallisen ja sosiologisen tarkastelukulman. Tämä yritys jóhti kirjaan Koulutus luokkayhteiskunnassa (Engeström 1970), jossa pyrittiin osoittamaan oppimisen ja sosialisaation yhteiskunnallis-taloudellinen määräytyminen. Niinpä vietin 1970-luvun alkupuoliskon laatimalla koulutuspoliittisia ohjelmia ja järjestämällä joukkokampanjoita opiskelijaliikkeessä - ja samanaikaisesti suunnittelemalla suurehkoja koulutusuudistuksia valtion komiteoissa ja opetusministeriössä. Nämä pyrinnöt johtivat joihinkin pysyviin tuloksiin, mutta päätyivät myös umpikujaan. Eivät ainoastaan yleiset poliittiset olot muuttuneet epäsuotuisiksi omasta työstämme alkoi puuttua pätevää sisältöä.

Palasin tutkimukseen, tällä kertaa psykologisesta näkökulmasta. Koululaisten maailmankuvan muodostumista koskenut projekti johti kirjaan Koululaisten mielikuvitus ja käyttäytyminen (Engeström 1979). Olin tämän työn aikana perehtynyt neuvostoliittolaisen psykologian kulttuurihistorialliseen koulukuntaan, eritoten toiminnan käsitteeseen. Mutta toiminnan ideaa käytettiin selittävänä käsitteenä yksilön psykologisten toimintojen tasolla. Ana- lyysin perusyksikkönä pysyi yksilö. Johtavan tai dominoivan toiminnan käsitettä (Leontjev, Elkonin) käytettiin selittämään psyykkisten ilmiöiden, kuten mielikuvituksen tai käytöshäiriöiden, yksilöllistä kehitystä. Samoin Davydovin dialektista teoriaa käsitteistä käytettiin selittämään yksilön tietoisuuden muotoja.

Kognitivismista on 1980-luvulla tullut psykologian ja kasvatustieteen valtavirta. Voiko kognitivismi ratkaista psykologisen ja yhteiskunnallisen dikotomian? Jouduin vakavasti vastakkain kognitivismin kanssa didaktisen teorian alueella. Tämä työ johti kolmeen kirjaan, joista ensimmäisessä suhtauduttiin kognitivismiin myönteisesti, seuraavassa kahdessa voimakkaan kriittisesti (Engeström 1982: Engeström 1983: Engeström 1984). Kognitivismi pitää epäilemättä ihmistä rakentajana - nimittäin yksilön päässä syntyvien kognitiivisten rakenteiden muokkaajana. Kognitivismin valtavirta ei ole kyennyt tutkimaan ihmistä esineiden ja yhteiskunnallisten rakenteiden aikaansaajana. Tämä toteamus teki kaksijakoisuuden ylittämisestä jälleen kerran akuutin teoreettisen välttämättömyyden.

Tämän käydessä minulle selväksi käytännön tutkimustyöni siirtyi enenevästi luokkahuoneista työpaikoille (Engeström \& Engeström 1984). Minä ja kollegani tajusimme, ettemme voineet tutkia oppimista työpaikalla ja työn kognitiivista hallintaa yksilöllisenä prosesseina tai ominaisuuksina. Liioin emme voineet tutkia kvalifikaatioiden ja organisaatioiden kehitystä puhtaasti sosio-ekonomisina, rakenteellisesti määräytyvinä ilmiöinä. Kumpikaan näistä perinteisistä lähestymistavoista ei vastannut sitä todellisuutta, jonka kohtasimme työpaikoilla. Ihmiset eivät olleet erillisiä koteloita eivätkä liioin ylhäältä annettujen rakenteiden lisiä. Näin uuden teoreettisen ja metodologisen kehyksen luomisesta tuli meille myös käytännöllinen välttämättömyys.

Oli aika ottaa vakavasti kulttuurihistoriallinen toimintateoria kaikkine merkityssisältöineen. Ensimmäinen askel tätä kohti edellyttää kontekstualismin omaksumista.

1) Lectio praecursoria väitöstilaisuudessa Helsingin yliopistossa 16.6.1987. 


\section{Konteksti}

Uudessa kirjassaan Cognition in Practice (painossa) Jean Lave käsittelee traditioita, joissa on pyritty sisällyttämään sosiaalinen konteksti psykologiseeı teoriaan ja tutkimukseen. Yksi näıstä traditioi ita on Roger Barkerin ekolog!n!n behaviorisıin muunnos, jossa kontekst!t määritellään ympärıstöllisesti annetuiksi "käyttäytymiskehyksiksi" (esım. Barker 1968). Vaikka tämä lähestymistapa onkin tehokas selitettäessä ja luokiteltaessa inhımillistä käyttäytymistä, se jättää vaiı vähän tilaa ihmisten muokkaamille uusille konteksteille. Kontekstit käsitetään helposti käyttäytymisen säiliöiksi, joita itseään inhimilliset toiminnat eivät kosketa.

Toinen, monivivahteisempi kontekstuaalinen traditio käsittää fenomenologiset, lingvistiset, etnometodologiset ja konstruktivistiset yritykset määritellä kontekstit sosiaalisiksi tilanteiksi, interaktiivisen kokemuksen avaruuk. siksi tai keskustelun alueiksi. Tämän perinteen huomattavina edustajina voidaan mainita Ervin Goffman (esim. 1975) ja Dell Hymes (esim. 1974). Vaikka kontekstit tässä nähdään henkilöiden välisinä rakennelmina, niitä käsitellään puhtaasti kielellisinä ja symbolisina kokonaisuuksina. Tämä saa kontekstin näyttämään joltakin sellaiselta, jonka kaksi tai useampi ihmistä voivat tahtoessaan keskinäisessä vuorovaikutuksessa synnyttää ikään kuin riippumatta tietyn kulttuurin syvään juurtuneista aineellisista käytännöistä, esineistä ja välineistä.

Toiminnan teorialle kontekstit eivät ole säiliöitä eivätkä liioin tilanteen mukaan luotuja kokemuksellisia avaruuksia. Kontekstit ovat toimintajärjestelmiä. Toimintajärjestelmä yhdistää tekijän, kohteen ja välineet (aineelliset välineet sekä myös merkit ja symbolit) yhtenäiseksi kokonaisuudeksi (Leontjev 1978). Toimintajärjestelmä käsittää sekä inhimillisen käyttäytymisen kohteeseen suuntautuvan tuottavan puolen että henkilöön suuntautuneen kommunikatiivisen puolen. Se on moninaisten välitysten mutkikas systeemi. Ehdotan, että tekijän, kohteen ja välineiden lisäksi toimintamalli analyysin perusyksikkönä sisältää aina yhteisön, työnjaon ja sääntöjen osatekijät ja keskinäisen vuorovaikutuksen.

Toimintajärjestelmän osatekijöiden kesken on käynnissä jatkuva muokkaus. Mutta toimintajärjestelmän elämä on myös epäjatkuvaa. Karttumisen ja suoraviivaisen kypsymisen ohella esiintyy kriisejä, mullistuksia ja laadullisia muutoksia. Näiden käsittämiseksi on omaksuttava historiallinen tarkastelutapa.

\section{Historia}

Yhteiskunta- tai käyttäytymistieteilijä ei voi välttää kehityksen mittapuiden käyttämistä. Kun luokittelemme ja arvioimme vastauksia tai kognitiivisia rakenteita, toimintamuotoja tai organisatorisia malleja, miten voimme tietää, mitkä niistä ovat kehittyneempiä kuin toiset? Arviomme perustuvat väistämättä julkilausumattomaan tai julkituotuun teoriaan kehityksestä.

Suljetut, lineaariset kehitysteoriat väittävät, että on olemassa yksi ainoa oikea kehityksen kulku tai sarja, joka johtaa määrättyyn kypsän täyttymyksen päätepisteeseen. Näistä näkökannoista tarkasteltuna historia ja henkinen kehitys vaikuttavat edistymiseltä primitiivisestä yhteisöstä (ja primitiivisestä ajattelusta) kehittyneeseen länsimaiseen sivilisaatioon (ja muodollis-loogiseen ajatteluun). Myös marxilainen käsitys sosio-ekonomisista rakenteista tulkitaan usein väärin opiksi mekaanisesti ennaltamäärätystä historian kulusta. Marx ja Engels näkivät asian toisin:

"Historia ei tee mitään, sillä 'ei ole mitään suunnatonta tahtoa', se 'ei käy mitään taisteluja'. Ihminen, todellinen elävä ihminen on se joka tekee kaiken tuon, joka omistaa ja taistelee; 'historia' ei ole ikään kuin erillinen henkilö, joka käyttää ihmistä välineenä omien päämääriensä saavuttamiseksi; historia ei ole mitään muuta kuin päämääräänsä tavoittelevan ihmisen toimintaa." (Marx \& Engels 1975, 93)

Sellaisten tutkijoiden kuin Michael Colen, Jack Goodyn, Ed Hutchinson ja Sylvia Scriberin ansiona on, että he ovat osoittaneet, ettei henkinen kehitys seuraa lineaarista rataa (katsaus löytyy Colelta 1987). Erittäin mutkikkaita ja abstrakteja ajattelun ja kommunikaation muotoja löytyy niin kutsuttujen "primitiivisten yhteiskuntien" elintärkeistä toiminnoista. Mutta tämä ei merkitse sitä, etteikö historiassa olisi mitään suuntaa, mitään edistystä.

Marx löysi edistyksen kriteerit tuotantovoimien kehityksestä, ihmisen kyvystä voittaa puute ja raadanta. Mutta tässä ei ole kysymys lineaarisesta määrällisestä kasvusta. Kun teollisuus ja automaatio korvaavat välittömän käsityön, ihmisestä tulee tuotannon ja inhimillisen kanssakäymisen "vartija ja säätelijä". Ihmisen oma näiden mutkikkaiden prosessien kollektiivinen hallitseminen, hänen kehityksensä "sosiaalisena yksilönä" muodostuu kehityksen todelliseksi mitaksi. (Marx 1973, 704-706)

Toiminnan teorian kannalta on olennaista hylätä lineaarinen näkemys ja omaksua syklinen käsitys historiasta. Syklisellä käsityksellä on kaksi tärkeää seuraamusta. Ensiksikin si- 
säisen levottomuuden ja laadullisen muutoksen nähdään olevan jatkuvasti läsnä jokaisessa kehityssyklin vaiheessa, ne eivät rajoitu poikkeuksellisiin kausiin historiassa ja ihmisen kehityksessä. Toiseksi, kehityssyklit käsittävät säännöllisesti epävarmuuden ja päättämättömyyden kausia, joiden aikana määrällisesti vähäinen yksilöllinen toiminta saattaa saada aikaan suuriakin laadullisia murroksia ja uusia rakenteita (katso Prigogine \& Stengers 1985).

Jotkut noista uusista rakenteista ovat tietyn toiminnan yhden ja saman kehitystyypin sisällä syntyviä uusia toimintatapoja - esim. liukuhihnatuotannon rationalisoidussa tyypissä. Jotkut uusista rakenteista merkitsevät tietyn toiminnan sisällä tapahtuvaa läpimurtoa uuteen kehitystyyppiin. Ja lopuksi jotkut uusista rakenteista ovat historiallisesti kehittymässä olevan uudenlaisen toiminnan rakennuskiviä - kuten ekspansiivinen oppimistoiminta omassa analyysissäni.

Ymmärtääksemme uusien toimintarkenteiden syntymisen meidän täytyy käsittää ristiriidat liikkeellepanevana voimana toimintajärjestelmien kehityksessä.

\section{Ristiriidat}

Aina kun toimintajärjestelmän joku perusosatekijä saa uuden ominaisuuden, tuon osatekijän ja järjestelmän jonkin toisen osatekijän välille syntyy pakottava ristiriita. Kun esimerkiksi potilaiden valitukset ja sairaudet ovat muuttuneet, lääkärin aineelliset ja käsitteelliset keinot diagnoosiin ja hoitoon ovat saattaneet käydä riittämättömiksi. Syntyy ristiriita muuttuneen kohteen ja lääkärin työtoiminnan perinteisten välineiden kesken.

Mutta näkyvät ristiriidat syntyvät puolestaan piilevistä ristiriidoista ja käyvät läpi useita muodonmuutoksia toimintajärjestelmän edetessä kehityskaarensa läpi. Tätä inhimillisen toiminnan aluetta ymmärretään kehnosti. Jopa dialektisen logiikan parhaat esitykset (esim. Iljenkov 1977) ovat vain abstrakteja likimääräiskuvauksia ekspansiivisen kehityksen ristiriitojen kautta tapahtuvasta etenemisestä. Klassiset kehitysromaanit, kertomukset keksinnöistä ja tutkimusmatkoista sekä huolelliset terapiatapausten tallennukset tarjoavat näistä asioista parasta saatavilla olevaa aineistoa.

Mutta miksi tyytyä jo olemassa olevaan aineistoon? Uutta ensi käden aineistoa ekspansiivisesta kehityksestä voidaan saada menemällä sısaan toimintajärjestelmään, jossa muutospaineet ovat kohoamassa. Mutta mukaanmeneminen edellyttää kehitysinterventioiden käsitettä tutkimusstrategiana.

\section{Interventiot}

Poliitikot, virkamiehet ja jotkut huipputeknologian alojen yrittäjät ovat vastikään ilmaisseet huolensa muuttuvien työprosessien ja aikuisten oppimisen välisiä keskinäisiä suhteita käsittelevän tutkimuksen riittämättömyydestä. Ennen kaikkea näytetään odotettavan a) erilaisten työprosessien pätevyysvaatimusten inventaarioita ja ennusteita ja b) tutkimuksia, jotka tuottavat käytännön ohjelmia aikuisten auttamiseksi pysymään työssä tapahtuvien muutosten tasalla.

Nämä kaksi odotusten ryhmää toistavat sitä dualismia, josta aloitin. Inventaariot ja ennusteet edustavat yläpuolellamme oievien yhteiskunnallisten rakenteiden objektiivisia vaatimuksia. Käytännön ohjelmat edustavat koteloituneita yksilöitä, jotka yrittävät seurata muutosta ja pysyä sen tasalla.

Mutkikkaita, riskialttiita teknologioita käsittelevässä tutkimuksessaan nimeltä Normal Accidents Charles Perrow (1984) antaa hyvän esimerkin tämän kaksijakoisuuden riittämättömyydestä. Kun teknologiset ja organisatoriset järjestelmät tulevat tarpeeksi mutkikkaiksi, juuri niiden monimutkaisuus synnyttää moninaisten häiriöiden vuorovaikutuksia, jotka eivät seuraa toisiaan suorana vaikutusten ketjuna, vaan kietoutuvat toisiinsa "epäloogisella", odottamattomalla tavalla. Nämä "normaalit onnettomuudet" tai "systeemionnettomuudet" sisältävät inhimillisten käyttäjien operaatioita ja tekoja. Pienet yksilölliset teot saattavat laajentua suuriksi katastrofeiksi kuten Three Mile Islandissa tai Tshernobylissä. Tässä meillä on ekspansiivisten tapahtumasarjojen tuomiopäivämuunnelma. Perrow osoittaa, kuinka naurettavaa on kuvitella, että tällaiset "normaalit onnettomuudet" voitaisiin välttää vallitsevalla kaksoisstrategialla eli a) täydellistämällä teknologiaa ja b) tehostamalla työntekijöiden perinteistä koulutusta.

Tarvitaankin juuri ekspansiivista oppimista, jossa tekijät tunnistavat historiallisen analyysin avulla oman toimintajärjestelmänsä sisäiset ristiriidat ja luovat mallin sen seuraavalle kehitysmuodolle. Vain näin voidaan toimia "normaaleja onnettomuuksia" vastaan ja ehkäistä ne. Interventio tutkimusstrategiana merkitsee tällaisen ekspansiivisen syklin liikkeelle panemista, tukemista, ohjaamista ja kirjaamista. Tällainen tutkimusstrategia hyökkää käytännössä, ei vain teoriassa, yhteiskunnallisen ja psykologisen välistä kaksijakoisuutta vastaan. 


\section{Lähteet}

Barker, R.G. 1968. Ecological psychology. Stanford: Stanford University Press.

Cole, M. 1987. Kulttuurihistoriallinen traditio ja vertaileva kulttuuritutkimus. Psykologia 22:2, liite.

Engeström, Y. 1970. Koulutus luokkayhteiskunnassa. Jyväskylä: Gummerus.

Engeström, Y. 1979. Koululaisten mielikuvitus ja käyttäytyminen rauhankasvatuksen kannalta tarkasteltuna. Rauhan- ja konfliktintutkimuslaitos. Tutkimuksia No. 19.

Engeström, Y. 1982. Perustietoa opetuksesta. Helsinki: Valtiovarainministeriö - Valtion painatuskeskus.

Engeström, Y. 1983. Oppimistoiminta ja opetustyö. Helsinki: Tutkijaliitto.

Engeström, Y. 1984. Orientointi opetuksessa. Valtion koulutuskeskus. Julkaisusarja B nro. 29.

Engeström, Y. \& Engeström, R. 1984. Siivoustyön hallinta ja siivoojien laadullinen koulutustarve.
Helsinki: ServiSystems.

Goffman, E. 1975. Frame analysis. New York: Harper \& Row.

Humes, D. 1974. Foundations of sociolinguistics. Philadelphia: University of Pennsylvania Press.

Ilyenkov, E.V. 1977. Dialectical logic: Essays on its history and theory. Moscow: Progress.

Lave, J. (in press). Cognition in practice. Cambridge: Cambridge University Press.

Leont'ev, A.N. 1978. Activity, consciousness, and personality. Englewood Cliffs: Prentice-Hall.

Marx, K. 1973. Grundrisse: Foundations of the critique of political economy (rough draft) Harmondsworth: Penguin Books.

Marx, K. \& Engels, F. 1975. Collected works. Vol. 4. Moscow: Progress.

Perrow, C. 1984. Normal accidents: Living with highrisk technologies. New York: Basic Books.

Prigogine, I. \& Stengers, I. 1985. Order out of chaos: Man's new dialogue with nature. London: Fontana Paperbacks.

\section{Helsingin yliopiston kasvatustieteiden osaston maaraamän virallisen vastaväittäjän lausunto fil.lis. Yrjö Engeströmin väitöskirjatutkimukses- ta Learning by expanding. An activity - theoretical approach to developmental research, kesäkuu 1987.}

Yhteenvetoni jakautuu kahteen osaan, väitöskirjan sisällön suppeaan kuvailuun ja arvioivaan yhteenvetoon.

\section{Kuvaileva yhteenveto}

Tämä väitöskirja käsittelee ongelmaa, joka on yhtä vanha kuin psykologiatiede itse, nimittäin opinalan jakautumista kahteen tieteeseen, jotka käyttävät keskenään yhteensopimattomia metodologioita. Tämän työn suuri voima on siinä, että se sekä tarjoaa ensyklopedisen erittelyn tämän kriisin monitahoisista ilmentymistä useilla psykologian haaroilla (mukaan lukien kognitiivinen, kehitys-, työ- ja kliininen psykologia) että tarjoaa laajan kokoavan metodologian tämän kriisin voittamiseksi erityisellä psykologisen muutoksen mekanismien ymmärtämisen alueella. Käsite "ekspansiivinen oppiminen" viittaa Engeströmin kokoavaan vaihtoehtoon.

Väitöskirja jakautuu viiteen lukuun, joista ensimmäisessä luonnehditaan ongelmaa useiden sen tällä hetkellä merkittävien ilmentymien kautta ja joista viimeisessä kootaan luvuissa 2-4 kehitelty uusi metodologinen lähestymistapa.

Väitöskirjan käsittelemän kriisin tunnuspiirteet tulevat esiin sarjassa toisiinsa kietoutuneita kaksijakoisuuksia. Nämä kaksijakoisuudet voidaan jäljittää ainakin Wundtiin asti, joka esitti, että tarvitaan kaksi psykologiaa, selittävä ja kuvaileva, jotta voidaan käsitellä kaikkia inhimillisen psykologisia prosesseja. Kuten Engeström yhteenvetona esittää, selittävä lähestymistapa, silloin kun sitä sovelletaan psykologisen muutoksen ongelmaan, turvautuu oppimisen käsitteeseen, käyttää muutosprosessin kuvaamisessa mekaanisia vertauskuvia ja saavuttaa parhaat tuloksensa selittäessään, kuinka organismit sopeutuvat ympäristönsä tapahtumiin. Kuvailevan lähestymistavan huomion keskipisteenä on ajatus kehityksestä luovana prosessina, jonka ai- kana syntyy laadullisesti uusia struktuureja. Se käyttää orgaanisia/biologisia vertauskuvia kuvaillessaan muutosprosessia, joka nähdään vallitsevien olosuhteiden ylittämisenä.

Kumpaakin lähestymistapaa arvostellaan oikeutetusti, ensinmainittua sen kyvyttömyydestä selittää, kuinka laadullisesti uudet käyttäytymismallit syntyvät ja toista sen taipumuksesta mystiikkaan ja epätäsmällisyyteen. Tässä kritiikissä käsitellään muita haitallisia kaksijakoisuuksia eritoten yksilön ja kollektiivin välistä, sisäisen ja ulkoisen välistä ja epähistoriallisen/ yleisen ja historillisen/erityisen välistä. Engeström pyrkii voittamaan nämä toisiinsa kietoutuvat kaksijakoisuudet luomalla kokoavan metodologian, jokka osoittaa mahdollisuuden kuvata ja eritellä tieteellisesti olosuhteet ylittäviä (ekspansiivisia) muutosprosesseja.

Luvun 2 ensimmainen osa palaa kaksijakoisuuden on- 
gelmaan Engeströmille keskeisellä alueella, oppimisessa ja kehityksessä, ja esittelee perusajatuksen, jota hän käyttää välttääkseen osoittamansa rajoituksen - kolmannen jäsenen tuomisen perusrakennekaavioon kulttuurisesti välitetyn inhimillisen toiminnan käsitteessä. Hän jäljittää kolme "sukuhaaraa", joissa käytetään kolmeosaista perusmallia ihmismielestä: semioottisen välittymisen filosofisen tradition, symbolisen interaktionismin psykologisen tradition ja välittyneen toiminnan teorian filosofis-psykologisen tradition. Keskeinen tässä analyysissä esille nouseva ongelma on, että kaikki yllämainitut lähestymistavat, kolmiosaisesta rakenteestaan huolimatta, pyrkivät suosimaan jotakin peruskolmion kaksijakoisuuksista. Tasapainoisen kolmijäsenisen rakenteen säilyttäminen muodostuu uuden metodologian avainvaatimukseksi.

Luvun 2 toinen osa kehittelee Engeströmin inhimillistä toimintaa kuvaavan perusrakennemallin inhimillisen toiminnan ilmaantumisesta siirtymässä apinasta homo sapiensiksi. Tämä malli eroaa aikaisemmista "kolmijäsenisistä" lähestymistavoista sikäli, että se yhdistää yhteen ainoaan struktuuriin edeltäjien erilliset kolmiomallit. Lisäksi se tarjoaa systemaattisen heuristisen menetelmän muutoksen tutkimiseksi järjestelmän sisällä osoittamalla, kuinka ristiriidat perusrakenteen eri solmukohdissa tai solmukohtien välisissä suhteissa "epätasapainottavat" rakenteen ja luovat ennakkoedellytykset uusien toimintajärjestelmien kehittymiselle.

Luvun 2 kolmannessa osassa esitetään muutoksesta vastaansanomattomia esimerkkejä, jotka keskittyvät koulutukseen, työhön, tieteeseen ja taiteeseen. Kunkin alan ekspansiivisesta oppimisesta esitetään kaaviomallit, joiden avulla näytetään, miten kukin niistä kasvaa ristiriidoista, jotka "työntävät esiin" uusia toimintarakenteita jostakin aiemmin tässä luvussa esitetyn perustoimintamallin solmukohdasta.
Luvun 2 lopussa nostetaan jälleen esiin sama ongelma kuin luvun alussa, kysymys siitä, kuinka uudet rakenteet syntyvät ihmisen yksilönkehityksessä, mutta tällä kertaa niin, että toiminnan teoria tuodaan mukaan mahdollisena vaihtoehtoisena selitysmallina. Engeström suhtautuu kriittisesti olemassa oleviin aihetta käsitteleviin toiminnanteoreettisiin lähestymistapoihin, joissa ei hänen mukaansa ole riittävästi nivelletty toisiinsa yksilöllisellä ja yhteiskunnallisella tasolla tapahtuvaa muutosta. Hän osoittaa myös, miten vaikeata on kohdata oppimistoimintaa koululuokissa (Piagetin ja Davydovin aiemmin hyvin eri tavalla merkille panema vaikeus). Nämä ongelmat johtavat kehitysmuutoksen käsittelyyn luvussa 3 ja erityisesti ongelmaan, miten uusi syntyy.

Luvussa 3 keskitytään selittämään ekspansiivisen oppimiseen liittyviä vaiheittaisia muutoksia. Jälleen käsitellään oppimisen ja kehityksen välistä perusongelmaa ja ratkaisua etsitään havainnosta, että toiminnalla on hierarkinen rakenne, johon yhdistyy yksilön ja sosiaalisen ryhmän välisen suhteen kaksinaisluonne. Kehitys nähdään siirtyminä yhdeltä toiminnan tasolta toiselle (ekspansio) ja siinä tavassa, jolla yksilöt muuttavat olemassa olevaa toimintajärjestelmää osana omaa kehitysprosessiaan

Kun nämä prosessit yhdistetään, tuloksena on "kehitysspiraali", joka johtaa tarvetilasta (ensisijainen ristiriita) kaksoissidokseen (toissijainen ristiriita), välineelliseen, tavoitteelliseen tekoon, joka johtaa tilapäiseen ratkaisuun ja lujittumisen jaksoon kunnes syntyy uusia ristiriitoja ja prosessi alkaa uudestaan. Näitä ajatuksia havainnollistetaan kahden kaunokirjallisen esimerkin avulla.

Tämän luvun merkittäviin käsitteellisiin ansioihin kuuluu käsitteen "lähikehityksen vyöhyke" laajentaminen niiden tapausten ulkopuolelle, joissa tietävämpi, voimakkaampi "toinen" edesauttaa lapsen kehitystä, sellaisten sosiaalisten käytäntöjen tasolle, jotka toimivat välittäjinä yhteiskunnan nykyisten toimintamuotojen ja sellaisten tulevien muotojen välillä, jotka syntyvät kollektiivisena vastauksena vallitseviin ritiriitoihin. Tämä uudelleenmuotoilu osoittaa Engeströmin pyrkimystä luoda sellaista "itsensä suosta nostamisen" metodologiaa, joka tekee mahdolliseksi luoda uutta tietoisesti. Olennaista tällaisessa prosessissa on ekspansiivisen oppimisen välineiden tunnistaminen, ongelma, jolle luku 4 on omistettu.

Luvussa 4 luodaan katsaus "ajattelun välineiden" histori alliseen kehitykseen etsittäessä välineitä, jotka vastaisivat ekspansiivisen oppimisen nousemista hyväksyttäväksi kulttuuriseksi käytännöksi. Yleiseksi välineeksi Engeström esittää uutta, Hegelin ja tiettyjen nykyisten neuvostopedagogien/filosofien ajatuksiin perustuvaa käsitystä käsitteistä abstraktista konkreettiseen kohoamisen prosessina.

Kolme "toissijaista" välinettä täydentää tätä käsitteitä koskevaa peruslähestymistapaa: ponnahduslaudat, mallit ja mikrokosmokset. Näitä ideoita valaistaan tieteen historiasta otetuin esimerkein (Mendelejevin jaksollista järjestelmää koskeva keksintö, atomiytimen halkaisemisen keksintö ja atomipommin rakentaminen).

Luvussa 3 ja 4 esiin nouseva merkittävä kysymys on ekspansiivisen oppimisen prosessin pitkä ajallinen ulottuvuus. Yksilön kehityksessä muutossykli saattaa vaatia kuukausia, yhteiskunnalliskulttuurisessa muutoksessa se saattaa viedä vuosikymmeniä tai -satoja. Kuinka se silloin voi olla aktuaaliempiirisen tutkimuksen kohteena teoreettisen ja historiallisen tutkimuksen lisäksi?

Engeström vastaa kysymykseen esittämällä vaiheittaisen tutkimusstrategian, jota hän nimittää ekspansiivisen kehittävän tutkimuksen metodologiseksi sykliksi. Tällaista tieteellisen toiminnan muotoa ei voida rajata yksinomaan 
perinteisiin psykologisiin menetelmiin, vaan siinä täytyy jälleen omaksua menetelmiä, joita naapuritieteet (sosiologia, antropologia jne.) sovelsivat silloin, kun psykologia syntyi ja sen menetelmäkriisi alkoi.

\section{Arvioiva yhteenveto}

Tämä väitöskirja on älyllinen voimannäyte, joka antaa merkittävän panoksen psykologian, kasvatustieteen ja useiden lähialojen pitkäaikaisten teoreettisten ja menetelmällisten ongelmien ratkaisemiseen. Kuvailevassa yhteenvedossa totesin, että alaamme vaivaavien kaksijakoisuuksien voittamiseen käytetään toiminta-lähestymistapaa. Tässä totean, että Engeströmin tapa lähestyä toiminnan teoriaa on ainutlaatuinen siinä, että toiminnasta tehdään siinä aito "kolmas osapuoli" tämän hetken psykologisessa keskustelussa tieteenalan kehityksestä. Hän osoittaa tämänkaltaisen teorian kehittelyssä senlaatuista vaikeiden teoreettisten ja metodologisten kysymysten tuntemusta ja käsityskykyä, joka asettaa hänet korkealle arvoasteikossa sellaisten nykyajan kognitiivisen psykologian edustajien joukossa kuin oman yliopistoni Donald Norman tai Neuvostoliiton Vladimir Zinchenko.

Toiminnan teoriaan tutustuneet tietävät, että se esitetään usein "periaatteessa" filosofis-menetelmällisenä vaihtoehtona olemassa oleville psykologisille lähestymistavoille, jotka alistetaan murskaavalle kritiikille ja hylätään. Hyvin usein toiminnan teorian omaksuminen julistetaan reduktionistisen psykologian ideologiseksi kumoamiseksi. Engeström ei lähde mukaan näihin yksipuolisiin lähestymistapoihin. Hänen lähestymistapansa suurena ansiona on, että hän näkee tarvittavan aitoa synteesiä, ei menneen yksipuolista hylkäämistä.

On vaikea antaa kuvaa siitä, miten vaikuttava Engeströmin laaja tapa käsitellä psykologista teoriaa on. En tunne yhtään yhtä laajaa ja syvää tämän aiheen tutkimusta. Hänen tietonsa kognitiivisesta psykologiasta ja kehitysteorioista ovat samanaikaisesti historiallisessa perspektiivissä syviä, sangen ajanmukaisia sekä erinomaisen analyyttisiä: monia osia tästä väitöskirjasta voitaisiin julkaista amerikkalaisissa aikakauslehdissä yksinkertaisesti siksi, että ne ovat korkealaatuisia kriittisiä katsauksia ja niissä kyetään verrattomalla tavalla käsittelemään niin englanniksi kuin saksaksi, venäjäksi, ruotsiksi ja suomeksi julkaistuja teoksia osoittaen niiden väliset aidot yhteydet.

Vielä suuremman vaikutuksen minuun on tehnyt Engeströmin kyky yhdistää aineksia, jotka ulottuvat kauas psykologian ulkopuolelle, kun hän rakentaa uutta metodologista järjestelmäänsä: ajattelen tässä sitä, kuinka erinomaisesti hän on hyödyntänyt semioottisten filosofien, Marxin, Hegelin ja neuvostoliittolaisen tradition parhaiden edustajien, Habermasin ja saksalaisten toiminnan teorian edustajien työtä sekä sitä, mikä on olennaista pedagogisessa teoriassa, antropologiassa, arkeologiassa, tieteen historiassa ja kirjallisuuskritiikissä. Näitä kauas ulottuvia lähteitä ei koskaan oteta mukaan itsetarkoituksellisesti; ne rikastuttavat ja vahvistavat esitettyä väitettä.

Kuten Engeström varsin oikein toteaa, on luotava uudenlainen empiirinen tutkimuskäytäntö hänen julista- miensa metodologisten periaatteiden toteuttamiseksi. Odotan innolla tätä vaihetta hänen työssään.

Kaiken kaikkiaan lisensiaatti Engeströmin työ osoittaa psykologian ja kasvatustieteen tieteellisen tutkimuksen korkeimpia laatuominaisuuksia. Sen tulokset luovat perustan oppimisen ja kehityksen välisen suhteen ratkaisemattoman ongelman ratkaisemiselle tavalla, jota pitäisi välittömästi soveltaa kasvatuskäytännön ja työn organisoinnin tärkeillä aloilla. Lisäksi sen kokonaisrakenne onnistuu yhdistämään uudestaan psykologian yhteensopimattomat osat niin, että sellaisilla tärkeillä inhimillisen elämän aloilla kuin taiteella ja kirjallisuudella on aito sijansa psykologian ja kasvatustieteen teoriassa sen sijaan, että ne toimisivat esoteerisina etuvartijoina. Näin ne rikastavat tulevan ihmisluontoa koskevan teorianmuodostuksen mahdollisuuksia.

Lisensiaatti Engeström puolusti työtään erittäin ansiokkaasti. Esitän varauksetta, että lisensiaatti Engeströmin väitöskirja hyväksytään korkeimpaan akateemiseen arvoon oikeuttavana opinnäytteenä.

\section{Michael Cole University of California, San Diego}

